gravity of the diver. Borelli returned to Messina in 1668 and in 1674 retired to Rome, where he lived under the protection of Queen Christina of Sweden. A morose, obstinate and quarrelsome man, he died of pleurisy on December 31, 1679.

\section{The Commonwealth Trans-Antarctic Expedition}

THE trans-Antarctic survey party led by Dr. Vivian Fuchs reached the South Pole on January 20, where they were met by Sir Edmund Hillary and RearAdmiral G. Dufek, commander of the American naval base at the Pole. The expedition, which consists of Dr. Fuchs and his term of eleven men, four 'Snocats' and a 'Weasel', with two dog teams and sledges, left Shackleton Base for South Ice on the Weddell Sea on November 24 and started from South Ice for the Pole on December 21. Throughout the journey the expedition has conducted a programme of scientific observations including seismic soundings every thirty miles, gravimetric readings every fifteen miles and meteorological observations every three hours, in connexion with the International Geophysical Year. It is reported that Dr. Fuchs proposes to continue his journey across the Antarctic continent to Scott Base on the Ross Sea using the depots of food and fuel established by Sir Edmund Hillary's earlier supporting party.

Tenth Anniversary of British Ocean Weather Ships

IN August 1957 British ocean weather ships completed ten years of service in the North Atlantic. The first, Weather Observer, arrived at station 'Juliett' $\left(53^{\circ} 50^{\prime}\right.$ N., $18^{\circ} 40^{\prime}$ W. $)$ on August 5, 1947, and transmitted her first observation to the Central Forecast Office, Dunstable, on that day, thereby inaugurating the active participation of the United Kingdom in the North Atlantic Station Agreement. The record of the ten years work is summarized by Comdr. C. E. N. Frankcom, marine superintendent of the Meteorological Office, in an article in the issue of the Meteorological Magazine of October 1957. Besides the usual surface observations, regular upper air ascents with radio-sonde and radar-wind balloons have been made, a difficult task in the high winds so often encountered at the ocean weather stations.

In addition to performing their meteorological work, the four ships have provided navigational assistance to aircraft, carried out oceanographic research, and been used for researches by other institutions, for example, in seismological work by the University of Cambridge. Ten of the marine staff have served throughout the decade and one meteorologist for six years. The ships employed, converted "Flower"-class naval corvettes, are showing wear after their war and ocean-station work and one of them is to be replaced by a larger "Castle". class frigate now being converted for its new duties. The new vessel, which may be followed by others of the same type, will be much more roomy and comfortable.

\section{U.S. National Astronomical Observatory}

The Nationel Science Foundation has entered into a contract with the Association of Universities for Research in Astronomy, Inc., for the construction, operation and maintenance of a U.S. national astronomical observatory. The Association, which has its principal office in Phoenix, Arizona, comprises the following Universities: California, Chicago, Harvard, Indiana, Michigan, Ohio State and Wis- consin. These Universities joined together to constitute a management group for the new observatory, because they have had experience in operating large observatories and have big programmes of research and graduate instruction in astronomy. As the project develops, it is expected that other universities and individuals will join the Association. The Board of Directors of the newly formed corporation consists of a scientific and an administrative representative of each of the seven participating universities, as follows: California: Dr. C. D. Shane, director, Lick Observatory; Mr. J. M. Miller, assistant vice-president, business affiairs; Chicago: Dr. G. P. Kuiper, director, Yerkes Observatory; Mr. W. B. Harrell, vice-president, business affairs; Harvard: Dr. D. H. Menzel, director, Harvard College Observatory; Mr. Edward Reynolds, administrative vice-president; Indiana : Dr. F. K. Edmondson, chairman, Department of Astronomy; Mr. J. A. Franklin, vice-president and treasurer ; Michigan: Dr. R. R. MeMath, director, McMath-Hulbert Observatory ; Mr. G. L. Lee, jun., controller; Ohio State : Dr. P. C. Keenan, professor of astronomy; Mr. C. F. Miller, controller; $W$ isconsin: Dr. A. E. Whitford, director, Washburn Observatory; Mr. A. W. Peterson, vice-president. The corporation appointed Dr. McMath president, Dr. Edmonson as vice-president, and Mr. J. M. Miller as secretary.

The new observatory, when completed, will be open for research to all qualified astronomers. Under the terms of the contract, it is hoped to equip the Observatory initially with a 36-in. and an 80-in. telescope. The National Science Foundation's appropriation for the fiscal year 1958 includes an item of $3 \cdot 1$ million dollars for construction of an optical observatory on a site which is to be selected as a result of extensive tests. The Foundation oarlier awarded grants totalling approximately 800,000 dollars to the University of Michigan to support studies leading to the establishment of such an observatory (see Nature, 178,$837 ; 1956$ ). After extensive studies under the direction of Dr. Aden B. Meinel, executive secretary of the Foundation's advisory panel for the observatory, the choice of site was narrowed to five locations : Kitt Peak (6,875 ft.), 40 miles south-west of Tucson, Arizona; Summit Mountain $(7,500 \mathrm{ft}),$.11 miles south of Williams; Chevalon Butte $(6,950 \mathrm{ft}$.), 40 miles south of Winslow; the Hualapai Mountains $(7,350 \mathrm{ft}),$.13 miles south of Kingman ; and Junipero Serra $(5,800 \mathrm{ft}),$.21 miles west of King City, California. A special committee, under the chairmanship of Dr. C. D. Shane, director of Lick Observatory, recently spent some time in Arizona reviewing the situation. As a result, site studies will be continued at Kitt Peak and Hualapai and at a new location on Mormon Mountain $(8,440$ ft.), 35 miles south of Flagstaff, but discontinued elsewhere because recent work has shown that the other sites are unsuitable. Temperature and wind velocity will continue to be measured and seeing conditions tested at the three remaining sites. Studies are expected to be completed by about June 30, 1958.

\section{British Group for Computation and Automatic} Control

THE British Conference on Automation and Computation is being organized in three sections, as follows: $(A)$ the British Group for the Engineering Applications of Automation; $(B)$ the British Group for Computation and Automatic Control ; and $(C)$ the 